Volumen 30, $\mathrm{N}^{\circ} 3$ Páginas 3-10

IDESIA (Chile) Septiembre-Diciembre, 2012

\title{
EDITORIAL
}

\section{La adopción de la biotecnología moderna y su compatibilidad con una agricultura sustentable}

\author{
The adoption of modern biotechnology and its suitability for sustainable agriculture
}

Rodomiro Ortiz

\author{
Profesor de Genética y \\ Fitomejoramiento, Departamento \\ de Fitomejoramiento y \\ Biotecnología, Universidad de \\ Ciencias Agrícolas de Suecia \\ (SLU), Sundsvagen 14, Box 101, \\ SE 23053, Alnarp, Sweden. \\ Email: rodomiro.ortiz@slu.se
}

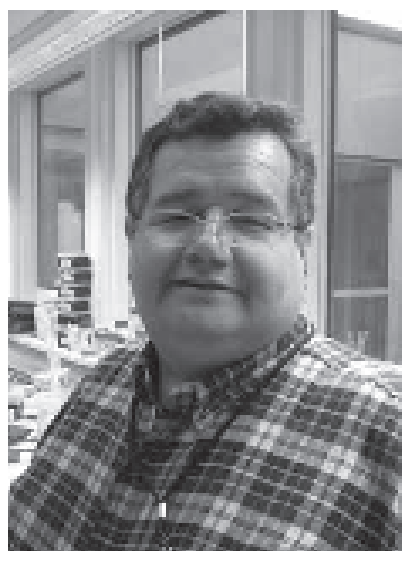

Professor, Genetics and Plant Breeding Dept. Plant Breeding and Biotechnology, Swedish University of Agricultural Sciences (SLU), Sundsvagen 14, Box 101, SE 23053, Alnarp, Sweden.

Email: rodomiro.ortiz@slu.se
La oferta mundial de alimentos tendrá que incrementarse significativamente para el $2050^{1}$. Se calcula que un $80 \%$ de este crecimiento futuro será en tierras actualmente en uso ya que el potencial de expansión de tierras para la agricultura es limitado. Es importante notar que a fines del siglo XIX un agricultor alimentaba a 2,5 personas, mientras que a fines del siglo XX éste alimentaba a 130 seres humanos. Por lo tanto, los cultivos del siglo XXI deberán ser resistentes a patógenos y pestes, tener resistencia a herbicidas y adaptación a estreses abióticos, poseer una mejor calidad nutritiva, y mostrar un mayor potencial de rendimiento para poder alimentar a la población del futuro y con casi una misma superficie agrícola ${ }^{2}$.

La biotecnología es toda técnica que utiliza organismos vivos o partes de estos organismos para modificar productos con fines prácticos en la medicina moderna, la agricultura y la industria. La biotecnología agrícola (o agrobiotecnología) puede usarse en el mejoramiento de nuevos cultivares para incrementar sus rendimientos y eficacia en el uso de insumos, y es muy útil para la caracterización y conservación de los recursos genéticos y el diagnóstico de las enfermedades y plagas de los cultivos.

Se puede considerar a la agrobiotecnología como una evolución de los métodos agrícolas tradicionales.
The world food supply will have to be increased significantly by $2050^{1}$. It has been estimated that $80 \%$ of this future growth will be on land currently in use, since the expansion potential of agricultural land is limited. It is important to note that at the end of the $19^{\text {th }}$ century a farmer fed 2.5 people, while at the end of the $20^{\text {th }}$ century he was feeding 130. Thus among other things, the crops of the $21^{\text {st }}$ century must be resistant to diseases and pests, be resistant to herbicides and adapted to abiotic stresses, have better nutritive quality and potential yield, to feed the population of the future with almost the same amount of agricultural land ${ }^{2}$.

Biotechnology includes all techniques which use live organisms or parts of them to modify products; it has practical uses in modern medicine, agriculture and industry. Agricultural biotechnology (or agrobiotechnology) may be used in the improvement of new cultivars to increase their yield and input use efficiency, and is very useful for the characterization and conservation of genetic resources and for the diagnosis of the diseases and pests of crops.

Agro-biotechnology may be considered as the evolution of traditional agricultural methods. In the 
Durante los últimos 10.000 años, la humanidad ha empleado su conocimiento sobre las plantas para mejorar la producción de alimentos. Los alimentos producidos con técnicas de biotecnología moderna han estado disponibles a partir de las últimas dos décadas. Sin embargo, la biotecnología se encuentra relacionada con los procesos que panaderos, cerveceros, vinicultores y productores de quesos han utilizado durante siglos al aplicar la biología en varios de los procesos para producir alimentos.

La biotecnología moderna incluye el análisis del ácido desoxirribonucleico (ADN), el ácido ribonucleico (ARN), las proteínas, y la genómica, la bioinformática y la ingeniería genética aplicadas a la modificación genética de organismos vivos. La ingeniería genética es el proceso de aislar ADN en un laboratorio, analizarlo e insertarlo en otro organismo. Esta biotecnología moderna puede y debe jugar un rol importante en el desarrollo de nuevos productos agrícolas, pero otros factores -tecnologías tradicionales de producción, el mejoramiento de las infraestructuras agrícolas y la distribución adecuada de los alimentos- no son menos importantes.

La agrobiotecnología, a través de la ingeniería genética, ofrece semillas transgénicas de cultivos resistentes a plagas y enfermedades, con niveles reducidos de micotoxinas y con resistencia a herbicidas que se adaptan mejor a las prácticas de la agricultura de conservación. Una planta transgénica es un vegetal que ha sido alterado genéticamente por medio de la ingeniería genética para contener ADN de otras fuentes.

Se ha anunciado el pronto lanzamiento de semillas transgénicas para adaptar los cultivos a estreses como la sequía ${ }^{3}$, o biofortificados con mejor y mayor contenido de micronutrientes. Por ejemplo, los granos biofortificados del "arroz dorado" transgénico contienen $\beta$-caroteno, que será una herramienta muy valiosa para luchar contra la mortalidad infantil y la ceguera asociada a la deficiencia de vitamina A (VAD) en la dieta. Como la severidad de VAD depende de los ingresos, los efectos positivos del "arroz dorado" son más pronunciados en los grupos de menores recursos. En un escenario pesimista, el costo de salvar un año de vida ajustados por incapacitación (DALY) es menos de US\$ 20 comparado con el costo de US\$ 134 a US\$ 599 por suplementación de la dieta con vitamina $\mathrm{A}^{4}$.

La ingeniería genética también puede usarse para mejorar cultivos que pueden mitigar el cambio climático. Más de la mitad del fertilizante aplicado al campo se volatiliza como óxido nitroso (que es aproximadamente el $6 \%$ de las emisiones de last ten thousand years humanity has employed its knowledge of plants to improve food production. Foods produced with modern biotechnological techniques have been available for two decades. However, biotechnology has been mostly related to the processes that makers of bread, beer, wine and cheese have used for centuries by applying biology to their food-producing processes.

Modern biotechnology includes the analysis of DNA (deoxyribonucleic acid), RNA (ribonucleic acid), proteins, genomics, bioinformatics and genetic engineering applied to the genetic modification of living organisms. Genetic engineering is the process of isolating, analyzing and modifying a section of DNA and inserting it into the DNA of another organism. Modern biotechnology can and must play an important role in the development of new agricultural products; however other factors traditional production technologies, improvement of agricultural infrastructure and adequate distribution of food - are no less important.

Agro-biotechnology, specifically genetic engineering, currently offers transgenic seeds of crops resistant to pests and diseases, with reduced levels of mycotoxins and with resistance to herbicides which adapt better to the practices of conservation agriculture. A transgenic plant is one which has been genetically altered by genetic engineering to contain DNA from another source or sources.

It has been announced that there will soon be transgenic seeds to adapt crops to stresses such as drought ${ }^{3}$, or bio-fortified with more and better micronutrient content. For example, the bio-fortified grains of transgenic "golden rice" have $\beta$-carotene, which will be a very valuable tool against infantile mortality and blindness associated with vitamin A-deficiency (VAD) in the diet. Since the severity of VAD depends on income, the positive effects of "golden rice" are more notable in the groups with less income. In a pessimist scenario, the cost of saving a year of life adjusted by incapacity (DALY) is less than US\$20, compared with US \$134-\$599 for supplementing the diet with vitamin $A^{4}$.

Genetic engineering may also be used to improve crops to mitigate climate change. More than half of the fertilizer applied in the field volatilizes as nitrous oxide (which represents about $6 \%$ of the 
gases invernaderos en países industrializados), es consumida por la presencia de microorganismos o se pierde por escorrentía, de modo tal que contaminan las aguas y causan zonas muertas. A través de la agrobiotecnología se pueden producir cultivos transgénicos que utilizan más eficientemente el nitrógeno y reducen la cantidad de fertilizante que pierden cada año los agricultores.

Los cultivos transgénicos actualmente en el mercado tienen como objetivo principal aumentar el nivel de sanidad vegetal de los cultivos mediante la introducción de resistencia a plagas causadas por insectos o enfermedades por virus, o mediante una mayor tolerancia a los herbicidas. La resistencia a los insectos se logra incorporando a los cultivos, a través de la ingeniería genética, el gen productor de toxinas de la bacteria Bacillus thuringiensis $(B t)$. Esta toxina se ha usado por décadas como un insecticida convencional en la agricultura y es inocua para el consumo humano. Los cultivos transgénicos que producen esta toxina en forma permanente requieren menores cantidades de insecticidas especialmente cuando la presión de las plagas es elevada. Se ha notado también un marcado incremento en la abundancia de tres tipos de depredadores generalistas de artrópodos (mariquitas, libélulas y arañas) y una disminución de la abundancia de las plagas de áfidos debido a la reducción de las aplicaciones de insecticida en campos de agricultores que siembran algodón-Bt en China. Como indican los autores de esta investigación, los depredadores pueden proporcionar servicios adicionales de control biológico por "spill-over" de los campos de algodón-Bt a los cultivos vecinos (maíz, maní y soja) ${ }^{5}$.

La resistencia a virus -que se ha obtenido por ejemplo al introducir un gen de ciertos virus que causan enfermedad en las plantas-reduce la susceptibilidad a enfermedades causadas por dichos virus, lo que da como resultado un rendimiento mayor de los cultivos ${ }^{6}$. La tolerancia a herbicidas se ha logrado mediante la introducción del gen de una bacteria que le confiere tolerancia a ciertos herbicidas (por ejemplo, el glifosato). Los cultivos transgénicos con tolerancia al glifosato han producido una reducción en la cantidad total de herbicidas utilizados especialmente cuando la presión de las malezas es elevada en campos de algodón, colza, maíz y soja.

En el 2011 se sembraron 160 millones de hectáreas de cultivos transgénicos (principalmente algodón, colza, maíz y soja) en 29 países del mundo (incluyendo varios de los mayores exportadores agrícolas $)^{7}$. Algunos de sus impactos y beneficios son la reducción de emisiones de gases de invernadero y en emissions of greenhouse gasses in industrialized countries), is consumed by microorganisms or lost in runoff, thus contaminating waters and causing dead zones. Using genetic engineering, transgenic crops can be produced which use nitrogen more efficiently and reduce the amount of fertilizer which farmers lose each year.

The main objective of the transgenic crops currently on the market is to increase crop health by introducing resistance to insect pests and virus diseases or better tolerance to herbicides. Resistance to insects is achieved by using genetic engineering to incorporate the toxin-producing gene of the bacterium Bacillus thuringiensis (Bt). This toxin has been used for decades as a conventional insecticide in agriculture and is innocuous to humans. Transgenic crops which produce this toxin permanently require less insecticide, especially when pest pressure is high. There has also been a marked increase in the abundance of three types of generalist arthropod predators (ladybird beetles, dragonflies and spiders) and a decrease in the abundance of aphid plagues due to the reduction in insecticide application in the fields which grow Bt-cotton in China. As the authors of this research indicated, predators may provide additional services of biological control from the "spill-over" from Bt-cotton fields to neighboring fields of corn, beans and soja ${ }^{5}$.

Resistance to viruses - which has been obtained for example by introducing a gene of certain viruses which cause disease in plants-reduces the susceptibility to diseases caused by these viruses, resulting in greater yield of the crops ${ }^{6}$. Herbicide tolerance has been achieved by introducing a gene from a bacterium which confers tolerance to certain herbicides (for example, gliphosphate). Transgenic crops with tolerance to gliphosphate have produced a reduction in the total amount of herbicides used, especially when weed pressure is high, such as in fields of cotton, raps, corn and soja.

In the year 2011, 160 million ha were seeded with transgenic crops (mainly cotton, raps, corn and soja) in 29 countries of the world (including several of the largest agricultural exporters $)^{7}$. Some of their impacts and benefits include the reduction in greenhouse gas emission and pesticide application, US\$10.1 billion in net income for farmers in 2007 and US\$ 44.1 for the period 1996-2007 
la aplicación de pesticidas, US\$ 10,1 mil millones de ingresos netos en las fincas del agricultor en el año 2007 y US\$ 44,1 mil millones para el período 1996-2007, haber añadido a la producción global 67,8 millones TM de soja, 62,4 millones TM de maíz, 6,85 millones TM extras de hilo de algodón y 4,44 millones TM de colza entre 1996 y $2007^{8}$. Esta producción adicional, debido a los cultivos transgénicos, ha contribuido (en términos de Kcal equivalentes) en alimentar a 402 millones de habitantes.

El algodón- $B t$ ha causado un aumento del $24 \%$ en el rendimiento de algodón por hectárea a través de reducir daños causados por plagas y un aumento de $50 \%$ en sus ganancias entre los pequeños productores en India. Sus beneficios se mantienen estables, incluso hay indicios de que han aumentado con el tiempo. La adopción del algodón- $B t$ ha aumentado los gastos de consumo (medida de estándar de vida) de sus agricultores en un $18 \%$ durante el período 2006-2008 en India ${ }^{9}$. El nivel de las ganancias al nivel de la finca depende si el agricultor adopta y retiene una tecnología, la cual se debe a varios factores y no solamente a su rendimiento, como, por ejemplo, la capacidad nacional de innovación agrícola, las regulaciones ambientales y de inocuidad de los alimentos, los derechos de propiedad intelectual, y los mercados de insumos agrícolas ${ }^{10}$.

El marco regulatorio de una tecnología novedosa debe considerar los riesgos asociados con esta innovación. La bioseguridad debe ser entendida por lo tanto como la protección de la salud humana, del ambiente y su biodiversidad con respecto a los riesgos conocidos o percibidos de la técnica o proyecto en cuestión, de acuerdo al estado actual de nuestros conocimientos. El análisis de riesgos consiste en estimar el impacto de los efectos intencionales y los no intencionales que pueden tener los organismos genéticamente modificados (OGM) sobre la inocuidad del alimento o del ambiente y su biodiversidad. A medida que avanza el conocimiento de sistemas biológicos será posible aplicar nuevas técnicas en la evaluación de la inocuidad alimentaria y la seguridad ambiental de los OGM. El debate actual acerca de la biotecnología moderna está centrado a menudo en los OGM, mientras que los agricultores ya utilizan muchos productos de la biotecnología como biofertilizantes y bioplaguicidas, además de numerosos instrumentos y aplicaciones en el sector agrícola.

Los alimentos hechos a base de cultivos genéticamente modificados que están disponibles en la actualidad (principalmente maíz, soja y colza) han sido juzgados seguros para comer, y los métodos utilizados para examinarlos han sido considerados and increasing global production of soya by 67.8 million MT and raps by 62.4 million MT between 1996 and $2007^{8}$. This additional production due to transgenic crops has contributed (in Kcal equivalents) to feeding 402 million people.

Bt-cotton has caused a $24 \%$ increase in the yield of cotton per ha, by reducing the damage caused by pests, and an increase of 50\% in earnings in small farmers in India. Its benefits have been stable; there are even indications that they have increased over time. The adoption of Bt-cotton increased consumption expenditures (a measure of living standard) of the farmers who grow it in India by $18 \%$ in the period 2006-20089. The level of profit at the level of the individual farm depends upon the farmer adopting and retaining the technology, which is due to various factors in addition to its yield, for example, the national capacity of agricultural innovation, environmental regulations and the innocuousness of the foods, intellectual property rights and agricultural provider markets ${ }^{10}$.

The regulatory framework of a new technology must consider the risks associated with this innovation. Biosecurity must thus be understood as protection of human health, the environment and its biodiversity with respect to the known or perceived risks of the technique or project according to our current state of knowledge. Risk analysis consists of estimating the impact of the intentional and unintentional effects which genetically modified organisms (GMO) may have on the innocuousness of the food and on the environment and its biodiversity. As our knowledge of biological systems improves it will be possible to apply new techniques in the evaluation of food innocuousness and environmental security of GMO. The current debate over modern biotechnology is often centered on GMO, although farmers already utilize many products of biotechnology as biofertilizers and biopesticides, as well as a number of instruments and applications in the agricultural sector.

Foods produced from genetically modified crops which are currently available (mainly corn, soya and raps) have been judged safe for consumption, and the methods used to examine them have been considered appropriate by the International Science Counsel (ISC) and concur with the opinions of the World Health Organization (WHO) and the Food 
apropiados por el Consejo Internacional de la Ciencia (ICSU) y concuerdan con las opiniones de la Organización Mundial de la Salud (OMS) y la Organización de las Naciones Unidas para la Agricultura y la Alimentación (FAO) ${ }^{11}$. Los científicos recomiendan que la evaluación de la seguridad alimentaria debe hacerse caso por caso y antes de introducir alimentos en base a cultivos transgénicos en el mercado. En estas evaluaciones, los alimentos derivados de plantas genéticamente modificadas se comparan a sus homólogos convencionales, generalmente considerados inocuos o seguros debido a su larga tradición de uso.

Como lo señala la $\mathrm{OMS}^{12}$, cualquier riesgo potencial para la salud humana de los alimentos en base a cultivos transgénicos generalmente se investiga a través de la evaluación de su inocuidad. Se evalúan los efectos directos sobre la salud (toxicidad), las tendencias a provocar una reacción alérgica (alergenicidad), los componentes específicos sospechosos de tener propiedades nutricionales o tóxicas, la estabilidad del gen insertado, los efectos nutricionales asociados con la modificación genética, y cualquier otro efecto no deseado que podría producirse por la inserción genética ${ }^{13}$. Los alimentos en base a OGM actualmente disponibles en el mercado internacional han pasado estas evaluaciones de riesgo y es improbable que presenten riesgos para la salud humana. Además, no se han demostrado efectos sobre la salud humana como resultado del consumo de dichos alimentos por la población general en los países donde fueron aprobados desde hace 1,5 décadas. La OMS también aconseja que las evaluaciones de riesgo en base a los principios del Codex Alimentarius y, donde corresponda, incluyendo el monitoreo post comercialización, debe ser la base para evaluar la inocuidad de los alimentos derivados de los OGM.

Las evaluaciones de riesgos para el medio ambiente incluyen a los OGM involucrados, así como el probable medio ambiente receptor ${ }^{14}$. La OMS opina que este proceso de evaluación abarca el análisis de las características del OGM, y sus efectos y estabilidad en el medio ambiente, combinado con las características ecológicas del medio ambiente en el que se introducirá. Estas evaluaciones deben también considerar los efectos no deseados que podrían ocurrir por la inserción del nuevo transgen.

La OMS advierte que las investigaciones para analizar cualquier riesgo al medio ambiente debe incluir la evaluación de efectos potencialmente perjudiciales sobre los insectos beneficiosos o una inducción más veloz de insectos resistentes, la and Agriculture Organization of the United Nations Organization $F A O^{11}$. Scientists recommend that the evaluation of food security be made case by case and before introducing foods based on transgenic crops into the market. In these evaluations, foods derived from genetically modified plants are compared with their conventional counterparts, which are generally considered innocuous or secure due to their long tradition of use.

As indicated by $\mathrm{WHO}^{12}$, any potential risk for human health of foods based on transgenic crops is generally investigated by evaluating their innocuousness. Evaluations include the direct effects on health (toxicity), tendencies to produce allergic reactions (allergenicity), the specific components suspected of having nutritional or toxic properties, the stability of the gene inserted, the nutritional effects associated with the genetic modification and all other undesired effects which may be produced by the genetic insertion ${ }^{13}$. Foods based on GMO currently available in the international marked have passed these risk evaluations and it is improbable that they are risks for human health. Additionally, effects on human health have not been demonstrated as a result of the consumption of these foods in the general populace in the countries where they have been approved for 15 years. WHO also recommends that risk evaluations should be based on the principles of the Codex Alimentarius, and where appropriate including post-commercialization monitoring, to evaluate the innocuousness of foods derived from GMO.

Risk evaluations for the environment include those of the GMO involved and of the probable receptor environment ${ }^{14}$. WHO suggests that the evaluation process should include the analysis of the characteristics of the GMO, its effects and stability in the environment, combined with the ecological characteristics of the environment in which it will be introduced. These evaluations should also consider the undesired effects which may occur due to the insertion of the new transgene. WHO warns that the research to analyze any environmental risk should include the evaluation of the potentially harmful effects on beneficial insects or a more rapid evolution of resistant insects, the potential generation of new plant pathogens, the potential harmful consequences for agro-biodiversity and wildlife, lower use of 
generación potencial de nuevos patógenos vegetales, las potenciales consecuencias perjudiciales para la agrobiodiversidad y la vida silvestre, un menor uso de la práctica importante de rotación de cultivos en ciertas situaciones locales, y el desplazamiento de genes de resistencia a los herbicidas a otras plantas. Por ejemplo, la investigación sobre los clones transgénicos de papa que proporcionan resistencia a los nematodos, que es una peste importante de la papa andina, señala que no hay daños en muchos organismos no objetivo, pero existe el flujo de genes a los parientes silvestres que crecen alrededor de los cultivos de papa ${ }^{15}$. Esta misma investigación indica que si se diera la introgresión estable de transgen, la integridad genética de estas especies silvestres podría ser alterada. Sin embargo, un cultivar transgénico macho-estéril proporciona una opción para la producción de papa transgénica resistente al nematodo que permitirá el uso de una papa transgénica que beneficiará a los agricultores andinos hasta que la posibilidad de introgresión estable del transgen a los parientes silvestres se determine. El progreso científico y el impacto en la sociedad rural de la papa transgénica en su centro de diversidad es posible sin comprometer el enfoque de precaución.

La conducta de los agricultores podrá tener una influencia significativa para que los transgenes se difundan, se expresen diferentemente y acumulen con sus variedades nativas. Sin embargo, las percepciones de los agricultores y consumidores de que los transgenes sean "contaminantes" y que las variedades nativas que contienen transgenes son "contaminadas" podría causar que estas variedades nativas sean rechazadas, lo que ocasionaría una pérdida directa de su biodiversidad ${ }^{16}$.

El flujo genético no es algo peculiar a las plantas transgénicas, ya que es tan antiguo como la vida misma. Este flujo genético ocurre cuando un organismo se cruza con una especie relacionada y pasa el ADN combinado a su progenie. El flujo genético que involucra a OGM impone un nuevo set de consideraciones ecológicas y económicas para ser analizadas por los científicos y gobernantes. Se debe analizar cada cultivo individualmente porque cada uno tiene muy distintos patrones de diversidad genética y diseminación. Igualmente es necesario desarrollar un testigo biológico aceptable para monitorear el flujo genético si es que la industria desea comercializar la más reciente generación de los cultivos transgénicos cuyo flujo genético es la preocupación dominante. Es muy importante estar familiarizado con los avances de la investigación que pueden cambiar las tendencias y pronósticos. the important practice of crop rotation in some local situations, and the transfer of herbicide resistance to other plants.

For example, research on transgenic potato clones which are resistant to nematodes, which is an important pest of the Andean potato, found that there were no damages in many non-object organisms; however, there is gene flow to the wild relatives which grow near potato crops ${ }^{15}$. This research also indicates that if there were stable introgression of the transgene, the integrity of these wild species could be altered. A male-sterile transgenic crop would provide an option for the production of transgenic potatoes resistant to nematodes, which would allow Andean farmers to benefit from the use of a transgenic potato until the possibility of a stable introgression of this transgene to wild relatives can be determined. Scientific progress and the impact in rural society of the transgenic potato in one of its centers of diversity are possible without compromising the focus on precaution.

The behavior of farmers may have a significant influence on the diffusion, differential expression and accumulation of transgenes in wild relatives. However, the perception of farmers and consumers that transgenes are "contaminants" and that native varieties which contain transgenes are "contaminated" could cause the rejection of these native varieties, which would produce a direct loss in their biodiversity ${ }^{16}$.

Interspecific gene flow is not restricted to transgenic plants; it is as old as life itself. This gene flow occurs when an organism crosses with a related species and the progeny inherit the combined DNA. The gene flow involving GMO imposes a new set of ecological and considerations which must be analyzed by scientists and government leaders. Each crop must be analyzed individually, because each has a different pattern of genetic diversity and dispersion. It is also necessary to develop an acceptable biological control to monitor gene flow if industry wants to commercialize the most recent generation of transgenic crops, whose gene flow is the dominant preoccupation. It is very important to be familiar with the advances in research which may change the tendencies and predictions. For example, using this knowledge and scientific protocols, researchers of the Instituto Nacional 
Por ejemplo, usando este conocimiento y protocolos científicos, investigadores del Instituto Nacional de Innovación Agraria (INIA) del Perú no detectaron ninguno de los eventos de maíz transgénico que fueron equivocadamente reportados como "cultivados" en el valle de Barranca (al norte de Lima) ${ }^{17}$.

Existen diversos acuerdos internacionales sobre los aspectos medioambientales de los cultivos transgénicos. El Convenio sobre la Diversidad Biológica (CBD) trata principalmente de la conservación y el uso sostenible de los ecosistemas, pero también de los efectos medioambientales de los OGM. El Protocolo de Cartagena sobre Bioinocuidad, que es parte de la CBD, regula la exportación y la importación de cultivos transgénicos. La capacidad del sector agrícola para proporcionar distintos productos es el factor clave para garantizar la libertad de los consumidores. En este contexto se define la coexistencia como la capacidad de los agricultores para poder escoger entre la producción de cultivos convencionales, ecológicos, o modificados genéticamente. Como la agricultura es un sistema abierto, la posibilidad de la presencia accidental de cultivos modificados genéticamente en los campos de aquellos no modificados genéticamente existe y por lo tanto es conveniente tomar las medidas técnicas y organizativas que sean necesarias para garantizar la coexistencia y, en consecuencia, la elección de los consumidores en la cadena alimentaria. El éxito de la coexistencia de diferentes sistemas de producción requiere el respeto mutuo y responsabilidad compartida por todas las partes, la comunicación entre las partes, y la aplicación de prácticas adecuadas. Es importante notar que el maíz- $B t$ cultivado cerca de maíz no- $B t$ proporciona a las plantas normales protección indirecta de las pestes ${ }^{18}$.

La biotecnología moderna, a través de la ingeniería genética, apoya al desarrollo del agro, y aunque no debe ser vista como una panacea contribuye a la agricultura sostenible reduciendo el uso de pesticidas o facilitando prácticas de agricultura de conservación, respondiendo a las exigencias sociales, ya que apunta a la mejora de las características para satisfacer las demandas de los usuarios, y siendo económicamente competitiva y rentable como lo demuestra el uso de algunos de sus productos por los agricultores en varios países. Un reciente análisis bioético, ${ }^{19}$ que considera el impacto social, cultural, ambiental y moral del uso de la biotecnología moderna en el mejoramiento transgénico de los cultivos, concluye claramente que para poder alimentar a tantas personas sin destruir el medio ambiente en este siglo es necesario tener una agricultura más productiva a de Innovación Agraria (INIA) of Peru did not find any of the events of transgenic maize which were incorrectly reported as "cultivated" in the Barranca Valley (north of Lima) $)^{17}$.

There are a number of international agreements on environmental aspects of transgenic crops. The Agreement on Biological Diversity (ABD) deals mainly with the conservation and sustainable use of ecosystems, but also with the environmental effects of GMO. The Cartagena Protocol on Bioinnocuousness, which is part of the $A B D$, regulates the exportation and importation of transgenic crops. The capacity of the agricultural sector to provide different products is the key factor to guarantee consumer freedom. In this context coexistence is defined as the capacity of farmers to choose between producing conventional, ecological or genetically modified crops. Since agriculture is an open system, the possibility of the accidental presence of genetically modified crops in the fields of non-modified crops exists, and therefore those technical and organization measures should be taken which are necessary to guarantee their coexistence, and in consequence the choices of consumers in the food chain. The success of the coexistence of different production systems requires mutual and respect and shared responsibility by all parties, communication among these parties and the application of adequate practices. It is important to note that Bt-corn growing near non-Bt-corn provides unmodified plants indirect protection against pests ${ }^{18}$.

Modern biotechnology, by applying genetic engineering foments agricultural development, and although it should not be perceived as a panacea, contributes to sustainable agriculture by reducing the use of pesticides and facilitating practices of conservation agriculture, responding to social requirements since it aims at improving characteristics to satisfy consumer demand, and being economically competitive and profitable as shown by the use of several of its products by farmers in various countries. A recent bioethics analysis $^{19}$ which considered the social, cultural, environmental and moral impacts of the use of modern biotechnology in the transgenic improvement of crops, clearly concluded that in order to feed so many people without destroying the environment in this century it is necessary to have more 
través de la agrobiotecnología, y que a pesar de todas las objeciones que se le presentan a esta también contribuirá con la conservación de la biodiversidad y la preservación del medio ambiente. production using agro-biotechnology, and that in spite of all the objections it will contribute to the conservation of biodiversity and the preservation of the environment.

\section{Literatura Citada}

1 Hubert, B.; Rosegrant, M.; van Boekel, M.A.J.S.; Ortiz, R. 2010. The future of food: scenarios for 2050. Crop Science 50: S33-S50.

2 Ortiz, R.

2011 Re-visiting the Green Revolution: seeking innovations for a changing World. Chronica Horticulturae 51 (1): 6-11.

3 Ortiz, R.

2009 Crop genetic engineering under global climate change. Annals of Arid Zone 47: 343-354.

4 Stein, A.J.; Sachdev, H.P.S.; Qaim, M. 2006 Potential impact and cost-effectiveness of Golden Rice. Nature Biotechnology 10: 1200-1201.

5 Lu, Y.; Wu, K.; Jiang, Y.; Guo, Y.; Desneux, N. 2012 Widespread adoption of Bt cotton and insecticide decrease promotes biocontrol services. Nature 487: 362-367.

6 Lius, S.; Manshardt, R.M.; Fitch, M.M.M.; Slightom, J.L.; Sanford, J.C.; Gonsalves, D.

1997. Pathogen-derived resistance provides papaya with effective protection against papaya ringspot virus. Molecular Breeding 3: 161-168.

7 James, C.

2011 Global status of commercialized biotech/GM crops: 2011. ISAAA Brief 43. Ithaca, New York: International Service for the Acquisition of Agri-biotech Applications.

8 Brookes, G.; Barfoot, P.

2008 Global impact of biotech crops: socio-economic and environmental effects, 1996-2006. AgBioForum 11: 21-38.

9 Kathague, J.; Qaim, M.

2012 Economic impacts and impact dynamics of Bt (Bacillus thuringiensis) cotton in India. Proceedings of the National Academy of Sciences (USA) www.pnas.org/cgi/doi/10.1073/ pnas. 1203647109.

10 Raney, $\mathrm{T}$.

2006 Economic impact of transgenic crops in developing countries. Current Opinion in Biotechnology 17: 1-5.
11 Silva Dias, J.; y Ortiz, R

2012 Transgenic vegetable crops: progress, potential and prospects. Plant Breeding Reviews 35: 151-246.

12 OMS

200220 Preguntas Sobre los Alimentos Genéticamente Modificados (GM). Ginebra, Suiza: Organización Mundial de la Salud. http://www.who.int/foodsafety/publications/ biotech/en/20questions_es.pdf

13 Lemaux, G.

2008 Genetically engineered plants and foods: a scientist's analysis of the issues (Part I). Annual Review of Plant Biology 59: 771-812.

14 Lemaux, G.

2009 Genetically engineered plants and foods: a scientist's analysis of the issues (Part II). Annual Review of Plant Biology 60: 511-559.

15 Celis, C.; Scurrah, M.; Cowgill, S.; Chumbiauca, S.; Green, J.; Franco, J.; Main, G.; Kienzebrink, D.; Visser R.G.F.; Atkinson, H.J.

2004 Environmental biosafety and transgenic potato in a centre of diversity for this crop. Nature 432: 222-225.

16 Bellon, M.R.; Berthaud, J.

2006 Traditional Mexican agricultural systems and the potential impacts of transgenic varieties on maize diversity. Agriculture and Human Values 23: 3-14.

17 Rimachi, L.F.; Alcántara, J.E.; Ortiz, R.

2011 Controversy over GM maize in Peru. Nature 470: 39.

18 Hutchinson, W.D. et al.

2010 Areawide suppression of European corn borer with Bt maize reaps savings to non-Bt maize growers. Science 330: 222-225.

19 Casquier, J.; Ortiz, R.

2012 Las semillas transgénicas: ¿Un debate bioético? Revista Derecho (PUCP) en prensa. 